\title{
Innovative Teaching in Town Planning in Architecture Curriculum
}

\author{
Prof. Parag G. Narkhede', Prof. Shilpa S. Nagapurkar ${ }^{2}$ \\ 1Adjunct Professor in Planning: Govt College of Engineering, Pune, \\ ${ }^{2}$ Associate Professor, D Y Patil School of Architetcure, Lohegaon,Pune. \\ ${ }^{1}$ parag114@gmail.com \\ 2shilpa.nagapurkar@gmail.com
}

\begin{abstract}
Bachelor of Architecture curriculum in Indian Universities includes Subject of Townplanning in its Fourth Year of study. It incorporates Planning Theory and Planningstudio both. While teaching Planning in Bachelor of Architecture curriculum, it isnecessary to decide upon the scope of the subject and needs to be orientedappropriately. The aim of teaching Planning to an Architecture student is definitelydifferent as it is essential to understand the need of learning Town Planning for anArchitect and its application in his practice. It is necessary to teach Planning in sync withArchitectural Design projects in concerned Year of Bachelor of Architecture curriculum.Generally the fourth year consists of Housing and urban Design projects in ArchitecturalDesign. Through appropriate content and teaching of planning subject, it needs to beseen that it is supporting and adding to the understanding of the Design curriculum. Outof various aspects of planning it is important to decide which of them are appropriate forArchitecture curriculum. The paper aims at studying the curriculum of selectedUniversities and associated pedagogy. Comparative analysis of these case studies isused to withdraw the inferences. Inferences are also based upon content of syllabus ofPlanning and its application to Architectural Practice. A common module of syllabus ofPlanning is prepared and appropriate pedagogy is suggested in the form of set ofguidelines. The same is applicable for framing the new syllabus structure for concernedsubject in Indian Universities. It consists of feedback from experts in the field of Architecture and Planning which contributes for finalizing content of the subject.
\end{abstract}

Keywords: Pedagogy, Architecture, Education, Housing, Urban Design

\section{Prof. Parag G. Narkhede ${ }^{1}$}

${ }^{1}$ Adjunct Professor in Planning: Govt College of

Engineering, Pune

${ }^{1}$ parag114@gmail.com

\section{Introduction:}

Bachelor of Architecture (B.Arch.) Curriculum is designed, guided, and regulated by theCouncil of Architecture, India. It has two Stages, first being of the duration of three yearsand second of two years. In this five years full time degree course, Stage-I of theprogram includes fundamentals of aesthetical and design aspects as well as basics ofstructures and technology. It also includes part of humanities and history. Some of theuniversities have included introduction to civilization and settlement planning studies inStage-I.

Stage-II includes advanced technological design aspects and part of legislation law.Professional practice subject of Town Planning or Urban Planning is also introduced inStag-II in Fourth year of B.Arch. It is the stage when students are simultaneouslyintroduced to housing projects in their Architectural Design and also developmentcontrol regulations. Thus it is necessary to frame a certain methodology while teachingplanning which would further be helping the students in learning housing. Theknowledge of planning should be delivered in a way that it will be an important valueaddition to the core subjects of Architectural Design program.

The scope of teaching Town Planning should be oriented in such a way that it shouldfacilitate students of Architecture to inculcate appropriate planning aspects in theirconcerned Architectural Design program.

Fourth Year of B. Arch also includes a long Architectural Design program based upon Urban Design. While teaching theories of Urban Design as a subject of Town Planning it should be seen that some of theories which are more relevant to Urban Design Program should be given importance over the others and needs to be taught first in the sequence of teaching and also with appropriate cases related to the Design Program.

Town planning studio has a few assignments based upon Urban Design. It is eventually possible to conduct joint studio of planning and design. It is always better to conduct one assignment based on one aspect with more inputs and depth rather than repeating it. It would also saves a good amount of time based upon the necessity of learning and understanding of housing and urban design it is necessary to include introduction to the basics of real 
estate management, social aspects and policies of housing while planning the syllabus of B. Arch degree course.

\section{Proposed Topics for Teachers Training Program for B.Arch. Teachers:}

1) Scope and Significance of the Subject: Town Planning in Architecture Curriculum.

2) Structure and content of the subject of Town Planning and its stage wise distribution among Five Years of B.Arch. degree Course.

3) Framing the syllabus of Town Planning in Second Stage of Architecture (Fourth Year) to support Architecture Design Curriculum.

4) Planning Theories and their application.

5) Settlement Study as an essential part of Architecture Design subject from initial stage.

6) Teaching methodology for Planning Legislation and Development Control Rules.

7) Integration of Architecture Design Studio and Planning Studio.

8) Individual sessions on the following topics:

- History / Civilization

- Regional Planning.

- Urban Design.

- Landscape Design.

- Socio-economical Aspects of Planning.

- Infrastructure Planning

- Urban Economics.

- Planning Administration.

- GIS and Remote Sensing.

- Environmental aspects of planning

- Planning Organisations

\section{Suggested Topics as an Essential Part of Town Planning in B. Arch Curriculum:}

In B. Arch curriculum various aspects of housing, Real Estate Management, \& Theories of Human settlements these are essential parts to be studied.

\section{Housing:}

Following topics are essential to be studied under the Housing, which currently not include in Town Planning study in B.Arch Curriculum-

Housing problems: Urbanization and Industrialization. Significance of housing in National Development Goals; Equity and efficiency parameters of housing; Current issues in housing.

Introduction to concepts of Housing Shortage, Housing Need, quantitative and qualitative aspects of housing.

Housing Demand - Understanding current methods of demand assessment.
Slums and squatters settlements - problems and possibilities, Socio-economic implication of slums clearance/ improvement of slum; sites and services schemes, squatter upgrading, incremental approach

Residential layouts, housing densities, neighbourhood unit, community facilities, Process of Public and private sector housing development process; social aspects of housing: built environment and human behaviour, evaluation of user satisfaction, housing norms and standards.

Understanding and evaluation of Housing Policy and programmes in India; five year plans, Central government policy; Policy framework for urban and rural housing; Comparative policy analysis; Housing for the low income groups; Cooperative housing, objectives and principles; management and financing of housing projects; investment in housing in public and private sectors.

Finance for housing: priority in the national plans - role of public and private agencies, role of cooperatives and various institutions.

\section{Real Estate Management:}

Real Estate Management is also one of the essential part of Town planning which having very much impact on town development.

Economic concepts of land, objectives and scope of land economics; economic principles of land uses; economic rent, land use and land values, market dynamics and impact on land use pattern, Development of Land and Real Property process- cost of development, source of finance, Economic aspects of land policies at various levels of decision making, Private ownership and social control of land all these are to be studied in Real Estate Management.

Addition to this, Land use restrictions, compensation and requisition taxation of capital gain on land, Valuation of land and property portfolios, Methods of valuation, Definition of real estate - physical, financial and social perspectives, Comparison of real estate to other investment avenues; real, local, national and global factors affecting real estate, Concepts of real estate analysis-Mapping supply to understand markets, Demand factors affecting real estate development, Demand-Supply Gap analysis, Real estate as facilitator of development, Transaction and renting of real estate, Lease deeds/ sale deeds, sale documents, registration; Mortgage and pledging., Real estate dynamics in metropolitan cities and tier I tier II and tier III cities, these are also essential topics for study.

\section{Introductory Part of Theories of Human Settlements:}

While studying Town Planning emphasis also should be given to theories of Human settlements. Relevance and Introduction to human settlements, history of Indian settlements, history of settlement patterns in the world during various periods, detail study of settlement theories, planning models \& study related to it, spatial aspects of settlement planningthese are the topics to be included are discuss in details as- 
Relevance and Introduction: Need of learning theories of human settlement. Relevance of the theories in present context, Applications of theories in policy making, Introduction to Ekistics, the science of human settlements, Evolution of planning theories over a period of time

History-Indian: Settlements in prehistoric, Vedic, Harappan ( Dholavira, Lothal, Surkotada, Banawali, Kalibangan, Mohen Jo Daro etc.) unto invasion of Turks in 1206 AD, Types of plans Described in Vedic Scripts ( Swastika, Karmukh, Dandaka, Padmaka etc. ).Settlements and their physical forms during various dynasties upto $18^{\text {th }}$ century and during colonization (Case studies - Jaipur, New Delhi etc.), Town planning after independence (Case studies - Chandigarh, Gandhinagar etc. Town plans

History -World:Settlement patterns during Sumerian, Egyptian, Crete - Minon and Mycenean, Greek, Roman, Mediaeval, Byzantine, Renaissance and Baroque period. (Case studies - Deir El Medine, Kahun, Ur, Uruk, Tape Gawrs, Tel, El Amarna, Babylon, Gournia, Knossos, Palaikastro, Athens, Miletus, Olynthus, Prine, Rome, Pompeii and Thebes etc.).

Detail study of Theories: Theories of city development including Concentric Zone Theory, Sector Theory, Multiple Nuclei Theory and other latest theories; Land use and land value theory of William Alonso; Ebenezer Howard's Garden City Concept; and Green Belt Concept; City as an organism: a physical, social, economic and political entity; Emerging Concepts: global city, inclusive city, safe city, etc.; City of the future and future of the city; Shadow cities, divided cities.

Planning Models and Related Study: Advocacy and Pluralism in Planning; Systems approach to planning: rationalistic and incremental approaches, mixed scanning and middle range planning; Equity planning; Political Economy Model; Types of development plans, plan making process. Contribution of individuals to city planning: Lewis Mumford, Patrick Geddes, Peter Hall, C.A.Doxiadis, Frank Loyd Wright etc; Dynamics of the growing city, impact of industrialization and urbanization, metropolis and megalopolis. Comparative analysis of similar aspects

Spatial Aspects of Settlement Planning:Urban Geography and its relevance to town planning. Settlement pattern, planning types by Harris and Ullman, Homer Hoyt,

E.W.Burgess. Central Place Theory by Christaller, Macroclimate, terrain and appropriate planning policy, Classification of Settlements based upon functions of city. Concept of gentrification, Rank Size Rule.

\section{Suggested Reference Books for Reading for Planning Studio in B.Arch. Course:}

1) Development Procedures under Town \& Country Planning Act-1947 by W C Graper (1949).

2) Urban Planning methods: research and Policy analysis by Ian Bracken (ISBN0-416-74870-8)
3) Urban Land Use Planning by F. Stuart Chapin Jr., Harper \& Brothers, Publishers, New York, USA

4) Urban pattern by Gallion (Crosby Lock Wood \& Sons Ltd)

5) The Subdivision and Site Plan Handbook by D Listokin\& C Walker

6) Organizing for Community Controlled Development, Renewing Civil Society by P Murphy \& James C.

7) Streets of Hope, The Fall and Rise of an Urban Neighborhood by P Medoff\& H Sklar

8) Building Communities from the Inside Out, A Path Toward Finding and Mobilizing a Community's Assets by John Kretzmann\& John McKnight

9) Neighbourhood Planning by Nick Gallent

10) Planning and design of townhouses and condominiums by R E Engstrom\& M R Putman

11) Developing Condominiums: Successful Strategies by Alexa Bach.

12) Brail K.R. (1990) Integrating GIS into Urban and Regional Planning. Alternative approaches for developing countries. Regional development Dialogue, Vol.11, No.3, UNCRD, Japan, 1990.

13) Cartwright T.J. (1991) Information Systems for Urban and Management in Developing Countries. The concept and reality, computers, environment and urban systems Vol.15, 1991.

\section{Guidelines regarding appropriate planning pedagogy in Architecture curriculum:}

Appropriate framework and content from the subject of Town Planning to be introduced in the subjects of Design and humanities in Stage-I of B.Arch.

Settlement study as an essential part of Architectural Design Subject in Stage-I

Appropriate hierarchy of settlements and correct typology from First Year B. Arch. to Fourth Year B.Arch.

Teaching of Civilization and settlement with emphasis on its evolution in terms of physical as well as social aspects.

While teaching town plan and civilization emphasis also should be given on building types an especially housing.

Environmental aspects of planning needs to incorporate teaching of environmental aspects of individual built form as well.

Though listed, detail and in depth teaching of only those planning theories which are relevant to Architectural Design and Practice remaining listed theories may be taught in brief as a part of developing the knowledge at a preliminary level.

Development planning and regional planning may be introduced at an introductory and basic level and not in 
depth. Instead Town Planning scheme may be taught in detail and as a part of planning studio so as to facilitate in inclusive learning of housing.

While teaching planning legislation more assignments needs to be focused upon development control regulations which helps students in their Architectural Design studio and in future practice as well.

Urban Design and housing, these units should be taught on priority basis and in detail as they are an important and relevant part of the Architectural Practice.

\section{Town Planning Exercises conducted in Architectural Curriculum:}

The objective of Town Planning subject in architecture curriculum is to provide town planning inputs to architectural design. It is intended that Town Planning exercises should run parallel to the topics being taken up in architectural design studio. The focus will be on application of town Planning theories in Town Planning studio.

Exercise: 1- Case studies of various types of housing.

Aim:To provide Town Planning inputs to architectural design project.

Objective:To study and analyse the various typologies of housing related to Architectural design project.

To study and analyse the area distribution and various land uses of a housing layout.

Methodology:Lecture on land use and various housing typology.Selection of a housing case study like a township. Study and analysis of various aspects like land use, housing typology, Landscape, services, etc.Observations on each aspect from above study.

Case study: Case study of Housing colonies having various housing typologies like-

1. Bungalow Plot Housing

2. Row houses.

3. Apartments - low rise / medium rise.

4. Combination of Bungalow/ row houses/ apartments.

Assignment:Housing case study has to be done on following aspects- (group of students) - on A1 size sheets.

1. Layout Plan.

2. Land use Map with areas.

3. Services Layout.

4. Landscape layout.

5. Various housing typology with area statement.

6. Observations.

Expected Learning outcome:Study and analyse the various typologies of housing, the area distribution and various land uses of a housing layout and application of the same in architectural design project.
Actual Learning outcome:Students are able to identify the housing scheme which having combination of various housing typologies. After studying \& visiting the actual housing scheme they are able to study the land use map, Layout of the scheme, various types of houses with the area \& percentage, calculation of FSI.etc. Studying \& documenting the data helped them to design housing scheme which their assignment of Architectural Design.

\section{Student's work:}

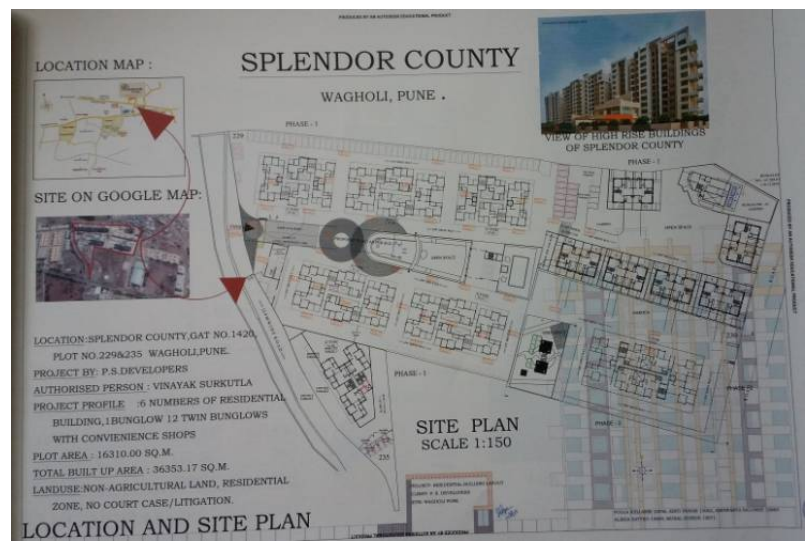

Fig: 1 Sit plan of Housing scheme

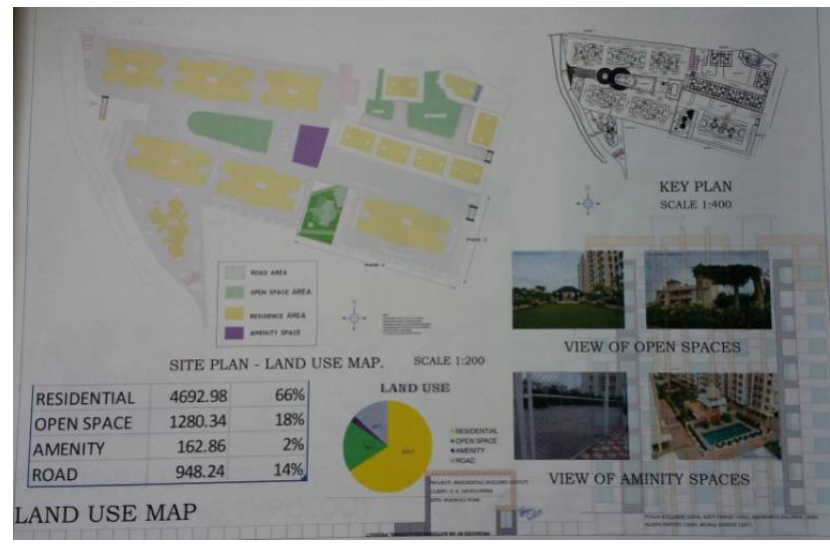

Fig: 2 Land use Map

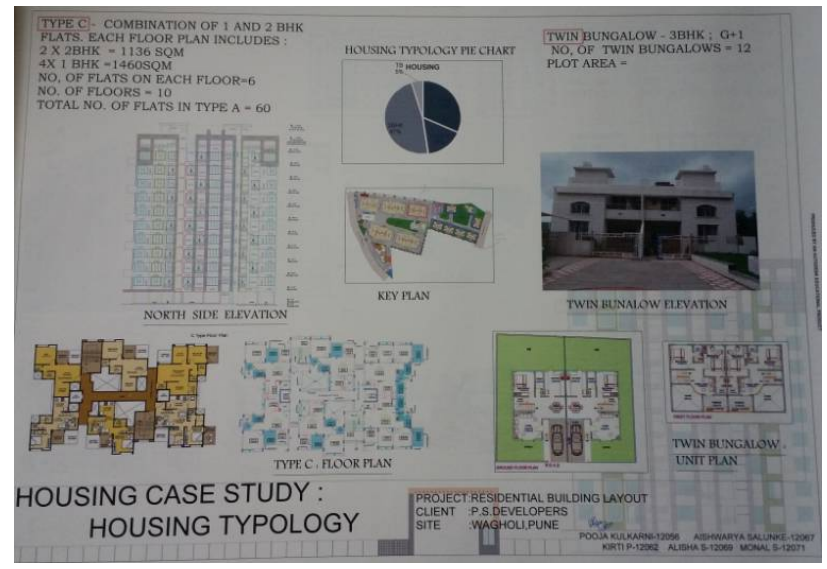

Fig: 3 Study of Various housing typologies 


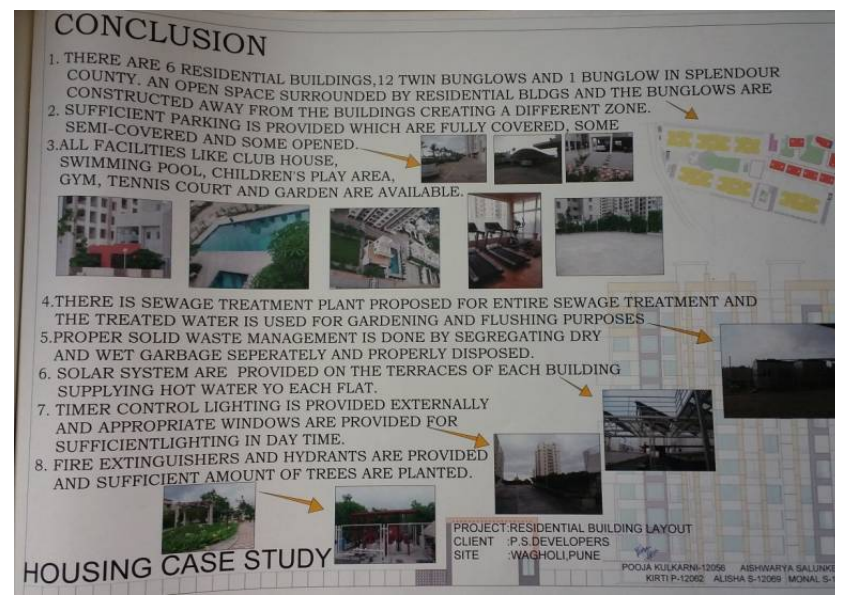

Fig: 4 Observations \& Conclusions

Exercise: 2-Study of existing Town and Town planning proposals.

Karjat has been identified for the study of existing town as it is having a municipal council and having tourist potential as situated in Western ghat range.

Study of Karjat town is consists of following heads-

Introduction - ( group study)

Land use- Existing land use map, area distribution. Proposed land use.

Roads \& connectivity - ( group study)

Infrastructure-( group study)

Public utilities / amenities-( group study)

Karjat as a tourist centre-( group study)

Administration - Local authority, working of local authority, duties \& powers, income \& expenditure, initiatives undertaken by local authority for development. Amenities required in future, Tourism potential, growth of industry.

Policies / guidelines for future development-(applicable to all groups)

Inference from study, conclusion, Policy / guidelines from each study head.

Expected Learning outcome:Role\& function of town as a small town centre in the development of region \& its surrounding. Study emphasis on serious challenges of growth of town \& its income/ expenditure. The issues of urbanization in the form of insufficient infrastructure, inadequate services, etc.

Actual Learning outcome: Policy guidelines suggested based on various surveys done help students to finalizing the proposal for town planning. Students learned to read the land use map, data collection at town level issues, analysis of data, various urban issues, etc.

Student's work:

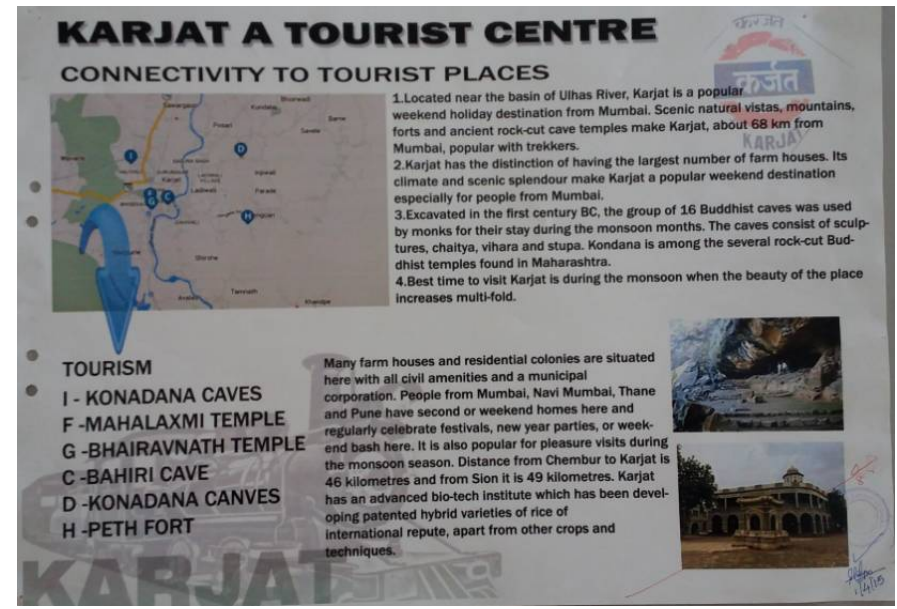

Fig: 5 Introduction \& connectivity to Karjat

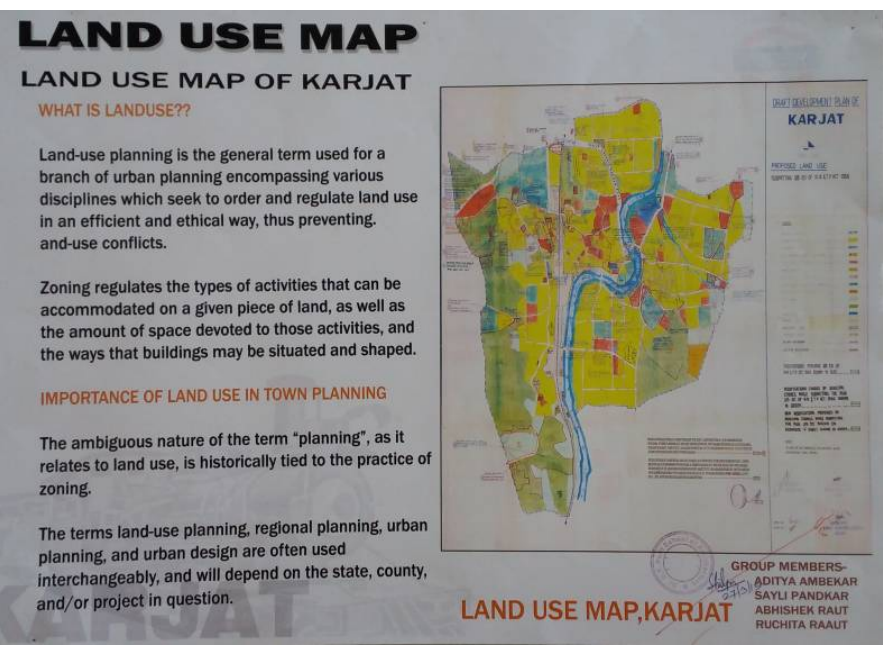

Fig: 6 Existing Land Use Map

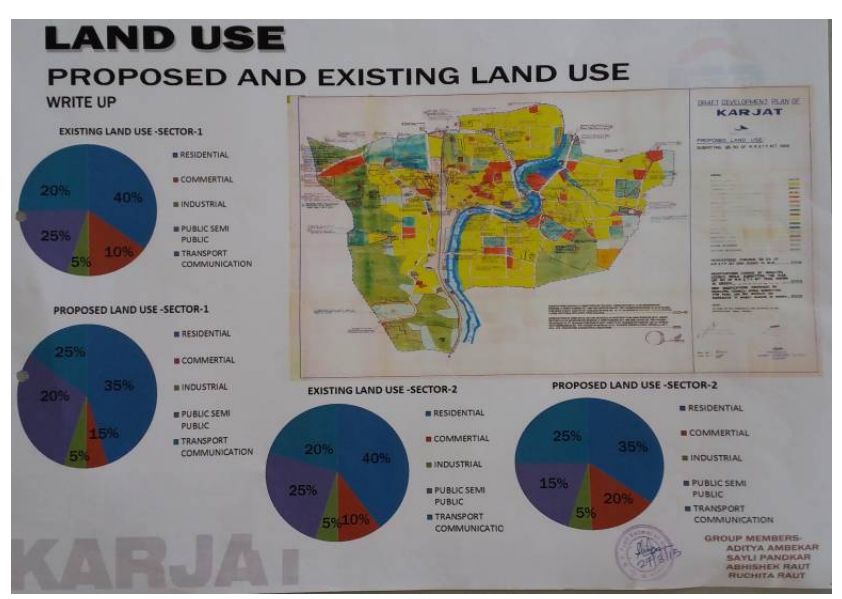

Fig: 7 Proposed \& Existing Land Use of Karjat 


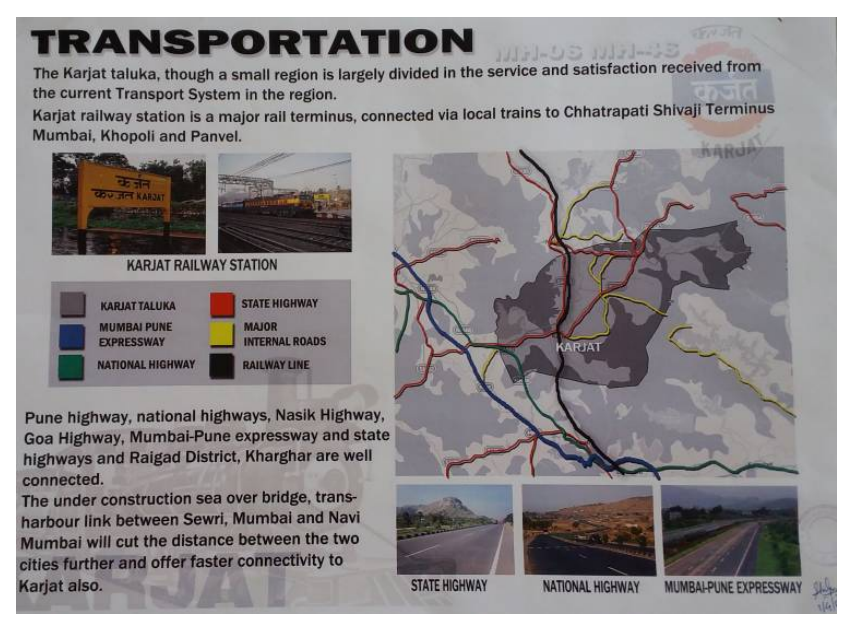

Fig: 8 Transportation Study.

Exercise: 3- Project based on Landscape Design, Urban design aspects in Town Planning.

Aim:To reduce the conflict between the movement space and the social space within the public spaces and create a people friendly environment.

Objective: To reduce conflict between the vehicular and pedestrian domains giving due priority to the pedestrian.

To adopt a contextual and climate friendly approach to the design of street furniture and public amenities (sense of place) - shopping arcades, outdoor seating, lighting, telephone kiosks, public toilets

To create an interesting shopping environment providing place for social interaction.

To provide for informal sector.

Relocation of on street parking and creation of parking pockets.

Methodology: Lecture on importance of urban design \& landscape design in Planning.Assignment based on the urban design \& landscape design aspects.

Case study: Study of existing scenario of the given area.

Assignment: 'Revitalization of Ferguson College Roadcreating a people friendly public domain.'

Study of existing situation of both sides of the roads.

Proposal guidelines for enhancing / redesign in terms of urban and landscape aspects for both the roads.

Expected Learning outcome: Understanding of variety of problems in the combination of the vehicular movement space and the social space within the same physical area, where the greatest amount of human contact and interaction takes place and providing guidelines as a solution.

Actual Learning outcome: Students learned that how the aspects of urban design \& landscape design plays important role in enhancing the urban area. Data collection $\&$ surveys are necessary to identify the current issues in urban area. Based on this students proposed some guidelines for revitalization of Ferguson College Road.
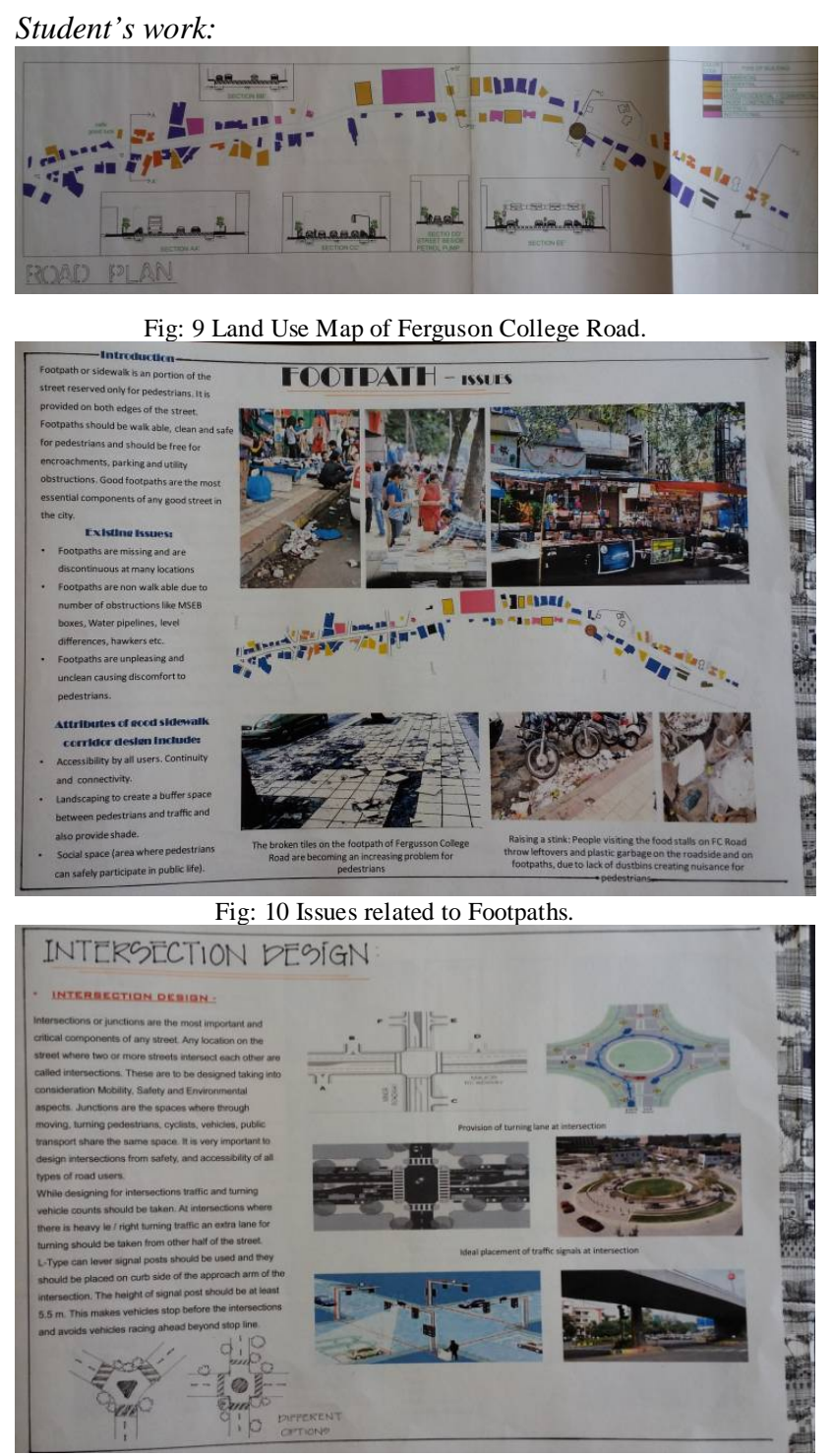

Fig: 12 Design proposals for transportation issues.

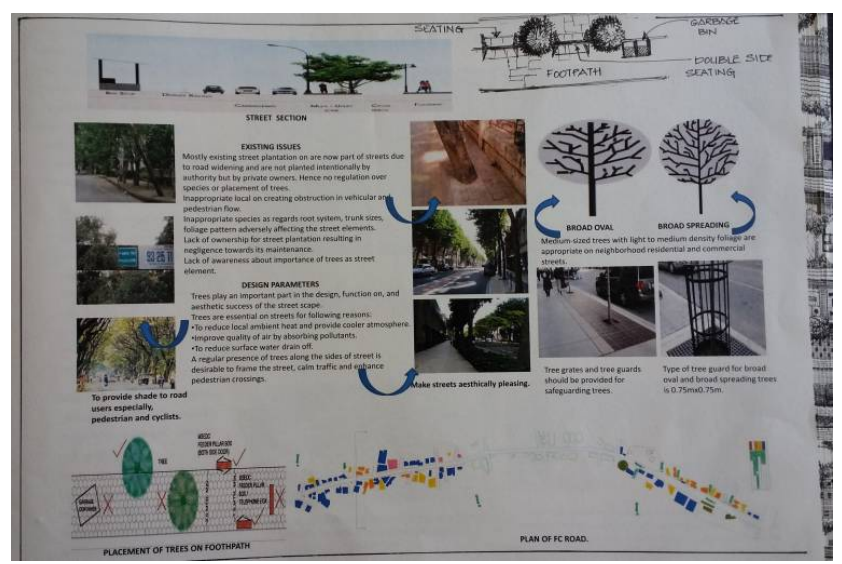

Fig: 13 Redesigning of street section.

References: 
Birch, E., L. (2009) The Urban and Regional Planning

Reader, London, Routledge.

Davies, J., S. and Imbroscio, D., L. (2009) Theories of Urban Politics, 2nd Edition, London, Sage.

Feinstein, S., and Campbell, S. (1998) Readings in Urban Theory, Oxford, Blackwell.

Fyfe, N., R., and Kenny, J., T. (2005) The Urban Geography Reader, London, Routledge.

Legates, R., and Stout, F. (2003) The City Reader, 3rd Edition, London, Routledge.

Reissman, L. (1964) The Urban Process: Cities in Industrial Societies,

Macmillian, The Free Press. Halsall, J GBER Vol 7 No 3 pp 83-85 85

Salama, A., M. (2009) Transformative Pedagogy in Architecture and Urbanism, Umbau-Verlag

\section{Acknowledgement:}

Fourth year B. Arch students' year 2014-15 \& 2015-16 of

D Y Patil School of Architecture, Lohegaon, ,Pune 